\title{
THE PHENOMENON OF VIRTUAL COMMUNICATION UNDER THE CONDITIONS OF THE BECOMING AN INFORMATION SOCIETY
}

\author{
Mariana Palchynska \\ DSc. (Philosophy), Associate Professor, Head of the Department of Philosophy, Psychology \\ and Pedagogy, O. S. Popov Odessa National Academy of Telecommunications, Ukraine \\ e-mail: petrovamaria2009@gmail.com,orcid.org/0000-0001-5860-9546
}

\section{Summary}

The article deals the virtual communication as one of the backbone elements of an information society. The large-scale spread of computer networks significantly transformed components such as communication processes, space, time and conceptual content. The formation an information society as a condition of multi-vector communication or polylogue, is constantly in the field of interaction and transitive provides the ability to design your own social identity. Particular attention is paid to the interactive aspects Virtual communication and transformation of communication patterns due to the lack of hard imperatives of social networking that contributes to the high variability of the personal self. Within the virtual space, produced a global computer network, develops specific language, a system of signs, symbols, symbols which set as their assimilation communicants ensures the effectiveness of the communication process. Virtual communication has become one of the factors of socio-cultural transformations of modern society, so an important tool for conceptual understanding of changes in the world is the analysis of the specifics of this aspect of social relations.

Keywords: modern society, information technologies, infocommunication interaction, virtual space, personality.

\section{DOI: https://doi.org/10.23856/3874}

\section{Introduction}

The relevance of the chosen topic resulted from the fact that currently in the world community there's the formation of a new type of social system - information, which is based on the exchange of information through technologies that create a specific socio-cultural reality. The formation of the information society has led to a change in the mechanisms of communication interaction already formed in society. Virtual communication has become one of the factors of modern society socio-cultural transformations, so an important tool for conceptualization of changes in the world is the analysis of the specifics of this social relations aspect, understanding of information and communication interactions as social reality part.

The aim of this article is to analyze the features of virtual communication in the conditions of the information society formation.

The level of scientific development of the problem. This topic has been partially considered by scientists who have studied the problems of the information society, an integral element of which is communication between users of computer networks. The researches of Bela D., Castels M., Lem S., I. Masuda, O. Tofler, Abdeev R., Alekseeva I., Voiskunsky A., Belinskaya A., Zhichkina A., Ivanova D., and others should be allocated.

Problems of communication, including virtual, were analyzed by J. Habermas, I. Wallerstein, N. Wiener, J. Baudrillard, N. Luhmann, M. McLuhan, V. Inozemtsev, L. Ionin, O. Rakitov, and others. 
However, the global introduction of information technology in almost all aspects of society life and the intensive integration of virtual communication into the existing system of public relations indicates the need for further scientific analysis of the phenomenon of virtual communication in the socio-philosophical aspect.

\section{Information society and infocommunication interaction}

The formation as a stage in the development of human civilization is a complex, multi-vector and controversial process. Since the middle of the twentieth century, Western sociologists and social philosophers have been discussing the entry of the most advanced countries into a qualitatively different stage of social development, characterized by them as a post-industrial or information society. The main criterion that distinguishes it is the crucial role of information and information technology in all aspects of human life. Theoretical concepts of social scientists, who analyze the formation of a new stage in the development of world civilization - "information stage, have identified the main conceptual vectors of its development" (Tourain A., 1984: 114). However, it should be noted that even in those countries where informatization has reached a fairly high level, the reality of the information world that exists at the moment, is radically different from those futurological predictions that were built at the beginning of its theoretical understanding. They took the form of the rapid development of mass media, especially television, the creation and mass distribution of personal computers, the construction of global information networks, the development of virtual reality technologies and other technological innovations. Taken together, these achievements have radically changed the life of society, bringing information activities, to the fore, i.e. activities related to the production, consumption, transmission and retention of information.

The formation of the information society modified the formed "ideas of society about time, space, distance and knowledge" (Wallerstein I., 1993: 16). This distinguishes the current leap of social development from previous technological revolutions based on the transformation and use of the properties of matter and energy. The changes brought to the modern world by the information revolution are integrated into the unique meaning of knowledge (Eco U., 2007). One of the critical factors of socio-cultural transformations in modern society is information and information technologies that change society at every structural level.

Society as a multifaceted system immanently implements various mechanisms and ways to optimize social interaction (Hassan I., 1987: 47). The development of society comes inter alia at the expense of the acceleration of info-communication exchange based on modern information technology as a means of social relations and information, which has become one of the leading resources of modern society. Characterizing the current stage of society development as information, as its system-forming feature, information stands out not only as a resource but also as a result of social interaction (Taylor W., 2005: 34). Therefore, one of the key elements of the information society is the subject of information interactions, which has the technology of social transformation. Information acts as a basic substrate of the individual life, carried out in a certain organizational order, given the nature of communication links and relationships of subjects that arise in the process of info-communication exchange.

Communication has always been one of the most important elements of the social interaction system, ensuring the continuation between generations, retransmission of cultural values, norms and rules, etc. during the development of civilization. It is a socially determined process realizes one of its fundamental social needs - the need for information exchange: "The communicative world is based on the fact that the messages in it are sent, perceived and 
understood. The variety of differentiated coordinated actions, which are in demand in today's complex social organization, depends on the extent to which it guarantees mutual understanding" (Nazarchuk A., 2000: 163).

Social processes organically contain a communication component, so social information serves as the basis for the effective functioning of social systems: "The social space of life is well-ordered and organized through a system of interactions, social cohesion and institutions. M. Weber's social action, related to the behaviour of others, takes into account the fact of interaction, which is the first prerequisite for any communicative act" (Malkovskaya I., 2007: 77).

Communication includes the information circulation within local and global social formations, interpersonal communication, ways of disseminating and receiving information: "The emergence of the philosophical theory of communication has become one of the most significant events in the philosophical life of the twentieth century. During the first, and especially the second half of the century, there was an intensive clarification of the meaning of those processes, functions and tasks associated with the information society formation and the development of communication technologies" (Nazarchuk A., 2000: 157).

Communicative space finds another subjective reality for the individual: "The media newspapers, magazines, movies and television, are often associated with entertainment and therefore are seen as something secondary in the lives of most people. Such a view is completely wrong. Mass communication affects many aspects of our lives. Even "relaxing" media, such as newspapers and television, have a huge impact on our worldview. This is not so much due to the specific impact on our positions, as because they become a means of access to knowledge on which public life depends" (Giddens A., 2009: 414).

With the information interaction expansion the dynamics of social processes increase: "Today in the "information society" or "knowledge society" the knowable subject is so captivated by messages coming from everywhere that it almost lost any cognitive autonomy and chances for critical reflection. The three factors of the "information society" are the total power of the media ("fourth power"), the existence of science exclusively in the form of a social institution, collective forms of knowledge production ("death of the author")" (Kasavin I., 2011: 48). There is an excess of available information, which causes "information stress" (Bodrov V., 2000).

\section{Virtual communication space}

In today's world, a significant role in communication processes is given to virtual space, which is determined by increased interactivity, which makes it unique as a way of communication: "Information and communication activity of people is massively transferred to online interaction through informatization" (Korytnikova N., 2007: 2). Virtual communication is an integral part of the socio-cultural space of modern society, inscribed in real social processes: "Media reality has found through electronic means of communication and screen culture density and the brightness comparable to true reality" (Nazarchuk A., 2000: 164).

Virtual communication is not a separate but a parallel type of social communication, while real communication is increasingly virtualized: "Today's communication is increasingly losing its individuality and character, emotion and style, resembling a set of standard phrases and words-symbols. The conversation becomes more and more "lump" and multiple, "hypertext". This can be especially observed in the example of "disembodied" remote forms of communication - telecommunications. Thus, communication in forums, chats and other ways of telecommunications are reduced to one-syllable and often short sentences, separate disparate remarks-statements, which repeat the already known opinions of the communication participants" (Korol A., 2011: 173). 
A significant share of information interactions is carried out using the global information environment, and this process is growing rapidly. Along with traditional forms of communication, society uses new forms for self-reproduction of society as a system: "Communication between people is something more essential, and interactive dialogues (widespread in electronic media and the Internet) are only a "preface" to a true communicative process. Communication is aimed at mutual understanding. Dialogue acts as a link between intersubjectivity in human society, even in a virtual environment. Hence the second component of the "information society", namely, "communicative". Communicative is born of interaction; through it "social" and "human" complement each other" (Malkovskaya I., 2007: 76).

In modern society conditions, social communication is increasingly moving into the virtual world of the global information network, which through its operation "creates a technical basis for attracting a huge audience in communication processes, which determines its global nature" (Voiskunsky A., 2001: 68). The virtual space reflects the processes of strengthening the virtualization of social communication, which provides the possibility of simultaneous contact or polylogue on a global scale.

M. Castells enshrines the importance of symbolic communication in the image of real virtuality. According to Castells, modern media with the use of multimedia and interactive technologies create a communicative system in which "reality, the material and symbolic existence of people, is completely immersed in virtual images, in a fictional world in which images are no longer a means of experience, but experience, which can enhance its impact on social reality" (Castells M., 2000: 320). He points to the inherent one-way communication on television and radio as a key problem of mass media: "there is no real process of communication as the interaction of the transmitting and receiving parties in the messages interpretation" (Castells M., 2000: 321). Considering the culture of real virtuality, he refers to the ideas of postmodernism and structuralism, which in this aspect are reduced to the position that cultures are created from communication processes, and all forms of communication are based on the production and consumption of signs and meanings. Analyzing the essence of the communication system that produces real virtuality, he defines it as follows: "It is a system in which reality itself, i.e. the material-symbolic existence of people, is fully captured, immersed in virtual images, and a fictional world in which external reflections are not simply on the screen experience is transmitted through, but become experience themselves" (Castells M., 2000: 351-352).

From the point of view of Jürgen Habermas, the state and form of social communication are considered as the most important indicator of the society technological development level and its socio-cultural features: "Extraverbal means - enter into the intersubjectivity of the relationship" (Habermas J., 2000: 128).

According to Jean Baudrillard, the basis of all forms of communication is the consumption of signs. So real communication is based solely on the operation of ideal objects. One of the most important characteristics of the media is their "non-transitivity" (Baudrillard J., 1994: 186). This disrupts the communicative process: "A person becomes a passive consumer, thus establishing a generalized order of consumption, in which you can not give, return or exchange, but only allowed to take and use" (Baudrillard J., 1994: 187). Baudrillard, in turn, believes that in terms of society of postmodern communication has ceased to be a conversation, because it has become a process of exchanging signs, a process of playing with signs. And the production of knowledge or information has turned into the production of simulacra signs without meaning, i.e. virtual production.

One of the factors influencing the socialization of the individual in modern society is the establishment of communicative links between the global computer network users: "Different 
groups in the struggle for the right to greater freedom of self-determination interact with similar groups in the world electronic network" (Bard A., Zoderkvist J., 2004: 108). In the virtual space there is forming of qualitatively new communication given its conceptual parameters: "The loss of the content of communication with the onset of the phase of its pattern, homogeneity and hypertext indicates hyperactivity of communication: increased frequency of telecommunications use, blogging diaries, hypertext information" (Hammet F., 1993: 173). Hyperactivity of communication, i.e. attempts to fill the deficit of communication dialogicity, is associated with the growing priority of information-communicative and regulatory function of communication over the affective-communicative function associated with the emotional sphere of human (Young K., 1998: 241).

\section{The concept and features of virtual communication}

Virtual communication is much less ritualized than social communication. Virtual space allows individuals to construct their own image, and its presentation takes place in the process of communication, and this image has a high dynamics: "Network communication, through anonymity, invisibility, security, allows you to create a network identity, achieving virtual impression management" (Malkovskaya I., 2007: 84).

One of the virtual communication characteristic features is the mismatch between the real person and his virtual image that he is trying to create. Cyberspace interaction contributes to the virtual personality constructing, which distances itself from the real social status to some extent. In this aspect, virtual space serves as a tool for the transformation of individual personal characteristics: "Technological progress leads to the imposition of a new mobile identity ... In the Web, human identity will be manifested only in the current context in order to undergo ... changes. The individual, a whole person, walks away, chained to his monotony, like a heavy backpack, in his place comes an individual, a multifaceted person" (Bard A., Zoderkvist J., 2004: 127). Communication in virtual reality is attractive by impersonality, the ability to construct and transform a virtual personality, as well as anonymity, which avoids responsibility for violating the role expectations due to the status of the individual. Cyberspace communication gives freedom of identification, thereby constructing a virtual personality with virtual status: "Very often there is deception or multiplication of identity - when the network identity of the user does not correspond to his real identity" (Turkle Sh., 1996: 172).

The virtual space produced by the global computer network is the basis of multi-vector communication and polylogue for both individuals and different social groups due to the expansion of interpersonal contacts by removing geographical and temporal barriers. Studies of virtual communication allow to state "the presence of specific features of a language, social hierarchy, indicators of social status and social norms" (Suler J., 1998: 277). In the modern era, contacts between people are becoming more virtually mediated.

The following can be distinguished as characteristic features of virtual communication:

- polyidentity of subjects involved in communicative processes;

- increasing the communication discursiveness (Kaledin D., 2000: 3);

- invariance of ways of receiving and producing information;

- expanding opportunities for socialization and professionalization.

Virtual space levels the boundaries of real and virtual, thus creating conditions for the construction of multi-vector self-presentation and self-realization, including in communicative processes. An integral element of virtual communication is the role behaviour of participants 
in the communicative process. It forms a specific role behaviour, which can be described as polyidentical, as the virtual space fully allows for multiple social self-representations: "The effect of dialogue occurs only when my partner with whom I communicate, not only generates text but also conveys to me his communicative intention, using all possible means. Moreover, in addition to verbal, there are also non-verbal means of communication - gestures, the transmission of visual images and so on. It is important to keep in mind that it is not the language itself that brings people the truth or new information, it is not language or speech we use for communicating, but semantic intentions" (Hammet F., 1993: 73).

\section{Conclusions}

Concluding the consideration of the selected topic, we can draw the following conclusions.

In the conditions of global changes inherent in the modern stage of civilization development - information stage, increasing the dynamics of social processes, and the search for the most effective forms of communication is becoming increasingly important. Інформаційне суспільство як тип соціального устрою передбачає формування як нового виду суспільних відносин, так і нового виду інформаційної взаємодії, що сприятимуть ефективній взаємодії суб'єктів у віртуальному інформаційному середовищі.

Analysis of the virtual communication peculiarities allows us to conclude that the information society formation has led to the emergence of virtual space, which is a special communicative environment, the operation of which has led to changes already formed in society communicative patterns. These changes are based primarily on anonymity, polyidentity of the virtual subject, the mediation of virtual communication by technical means, the absence of temporal and spatial barriers, etc., which allows independent modelling of the communicative space of both individuals and social groups.

Virtual communication is ambivalent. The positive consequences include the possibility of compensating for the lack of communication in social reality, the more noticeable negative consequences are additive behaviour, which leads to the minimization of real social communication necessary for effective social interaction within a particular social system.

Communication as a system-forming element of individual socialization in the cyberspace activates the interaction between a traditional culture (values, religion, knowledge inherited from previous generations) and a dynamic culture of virtual space. Communication as a system-forming element of socialization in the virtual space is associated with digital, remote and multimedia mode of communication. Depending on the nature and intensity of inclusion in the virtual space, this kind of communication can be extremely concise, but also visually and audio-saturated. In addition, virtual communication can be considered a virtually exclusive translator of certain code. On the one hand, infocommunication technologies retransmit mass culture, on the other hand, they are retransmit individualized culture, because the users can make its own content of communication.

\section{References}

Bard A., Zoderkvist J. (2004) Novaya pravyaschaya elita i zhizn posle kapitalizma [Netocracy. The new ruling elite and Life After Capitalism]. SPb.: Piter, 252 p. [in Russian]

Baudrillard J. (1994) Simulacra and Simulation. Michigan: University of Michigan Press. $320 \mathrm{p}$. 
Bodrov V. (2000) Informatsionnyiy stress [The Information stress]. Moskow: Editorial, 352 p. [in Russian]

Castells M. (2000) Informatsionnaya epoha: ekonomika, obschestvo, kultura [The Information Age: economy, society, culture]. Moskow: Logos, 608 p. [in Russian]

Giddens A. (2009) Sociology. Polity Press, 2009. - 1183 p.

Habermas J. (2000) Moralnoe soznanie i kommunikativnoe deystvie [Moral consciousness and communicative action]. SPb.: Nauka, 380p. [in Russian]

Hassan I. (1987) The postmodern turn. Essay in postmodern theory zand culture. Ohio: Ohio State University Press, 267 p.

Hammet F. (1993) Virtual reality. N.Y., 230 p.

Kaledin D. (2000) Haos, set i nauchnyie issledovaniya [Chaos, network, and research]. NG-nauka. 20 december. P. 3. [in Russian]

Kasavin I. (2011) Znanie i kommunikatsiya: $k$ sovremennyim diskussiyam $v$ analiticheskoy filosofii [Knowledge and communication: a contemporary debates in analytical philosophy]. Voprosyi filosofii. No. 6. 173-186 pp. [in Russian]

Korol A. (2011) Obschenie i problemyi distantsionnogo obrazovaniya [Communication and problems of distance education]. Voprosyi filosofii. No.6. 173-186 pp. [in Russian]

Korytnikova $N$. (2007) Sotsialnyie posledstviya razvitiya Internet kak sredstva proizvodstva setevyih kommunikatsiy [The social consequences of the development of the Internet as a the means of production of network communications] Retrieved from: http://www.isras.ru/ socis_2007_2.html [in Russian]

Malkovskaya I. (2007) Profil informatsionno - kommunikativnogo obschestva [Profile information-communicative society] // SOTSIS. No. 2. 76-85 pp. [in Russian]

Nazarchuk A. (2000) Ideya kommunikatsii $i$ novyie filosofskie ponyatiya XX veka [The idea of communication and new philosophical concepts The twentieth century]. Voprosyi filosofii. No. 5. 157-166 pp. [in Russian]

Suler J. (1998) Mom, Dad, Computer. Transference Reactions to Computers. Rider University. P. 275-294.

Taylor W. (2005) The e-Volution of the i-Society in the Business of e-Governance // UNESCO between two phases of the World Summit on the Information Society. -Moskow: Institute of the Information Society Press. 55 P.

Tourain A. (1984) The waning sociological image of social life // International jornal of comparative sociology. № 1-2. p. 112-126.

Turkle Sh. (1996) Parallel lives: working on identity in virtual space // Constructing the self in a mediated world: inquiries in social construction. N.Y. p. 156-175.

Voiskunsky A. (2001) Metaforyi Interneta [Metaphors of Internet] // Voprosyi filosofii. 2001. No. 11. 64-79 pp. [in Russian]

Wallerstein I. (1993) The Time Space of World-Systems Analysis: A Philosophical Essay. Historical Geography. XXIII, V2. p. 5-27.

Young K. (1998) Internet addiction: The emergence of a new clinical disorder. CyberPsychology and Behavior. № 3 (1). p. 237-244.

Eco U. (2007) Turning back the clock. London: Harvill Seeker. 134 p. 